Review and Meta-analysis

\title{
Birth by caesarean section and offspring overweight and obe- sity in adult life: a systematic review and meta-analysis Firstname
}

\author{
Chiavarini ${ }^{1}$, Manuela; De Socio ${ }^{2,}$ Benedetta; Giacchetta ${ }^{3 *}$, Irene; Fabiani ${ }^{4}$, Roberto
}

1 Department of Medicine and Surgery, Section of Public Heath, University of Perugia, Italy

2 Degree in Nursing and Midwifery science, University of Perugia, Italy

3 Department of Medicine and Surgery, Section of Public Heath, School of Hygiene and Preventive Medicine, University of Perugia, Italy

4 Department of Chemistry, Biology and Biotechnology, University of Perugia, Italy

* Correspondence: irene.giacchetta@gmail.com;

\begin{abstract}
Overweight/obesity is one of the most important health problem worldwide. Birth by cesarean section has been shown to influence long-term health outcome including obesity. The aim of this systematic review-meta-analysis is to examine whether cesarean section increases the risk of offspring' s overweight/obesity.

The study follows the PRISMA and MOOSE guidelines. A systematic literature search was conducted on Scopus, PubMed, and WoS until December 2020. For inclusion, studies must have reported either (I) both Birth by cesarean section and adult ( $\geq 18$ years) offspring BMI, (II) cohort or case-control study design and (III) a risk estimate. Heterogeneity testing was performed using Cochran's Q and I2 statistics. Publication bias was assessed by Egger's test and Begg's test. Metaanalysis was performed through a random effect model.
\end{abstract}

Eleven studies with a combined population of 180.408 subjects were included in the meta-analysis. The overall analysis $(n=18)$ yielded a combined risk estimate for overweight/obesity of $1.19(95 \%$ CI 1.08-1.31) and the test of heterogeneity resulted $\mathrm{Q}=53,37$ (I2 $=70,37 \%, \mathrm{P} \leq 0 \bullet 0001)$. The risk of offspring obesity is 1.23 (95\% CI 1.09-1.39) and the test of heterogeneity resulted $Q=39.50$ (I2= 72,15\%, $\mathrm{P} \leq 0 \bullet 0001)$.

Children born by cesarean section have an increased risk of developing obesity in adulthood

Keywords: cesarean section, body mass index, obesity, meta-analysis

\section{Introduction}

Overweight and obesity represent relevant public health concerns worldwide. The prevalence of obesity has been increasing significantly in the past two decades and overweight/obesity is now recognized as a global epidemic. In 2016, $13 \%$ of the world's adult population were obese. The prevalence of obesity was about $30 \%$ in China and in USA and $25 \%$ in Europe. [1,2]. A recent NEJM report estimated that, by 2030, nearly half of adults in the USA will have obesity, with a prevalence not below $35 \%$ in any state, and nearly one in four will have severe obesity, with a prevalence higher than $25 \%$ in 25 states [3]. Overweight and obesity are associated with an increased risk of Non-Communicable Diseases (NCDs) and are responsible for about 4 million deaths every year worldwide. Reducing by one third premature deaths by NCDs is one of the targets of the 2030 Agenda for Sustainable Development of the United Nations [4, 5, 6]. Birth by cesarean section (CS) has been shown to influence health outcome; CS rates are increasing globally, accounting for more than $20 \%$ worldwide births.[7]. Given the increasing use of CS and the growing 
evidence on its effects on the health of mother and the effects on children, a deeper knowledge of its long-term effects/impact on offspring's adulthood health status has become crucial [8]. Recent literature showed that babies born by CS have different hormonal and bacterial patterns and that this fact can change neonatal physiology and health outcomes [9-13]. Subjects born by CS present increased risk of immune-related diseases in later life such as allergies [9], asthma [10], celiac disease [11], type 1 diabetes [12], and metabolic and cardiovascular disease risk factors such as elevate systolic blood pressure, excess fat mass and high body mass index BMI (13). Two meta-analyses, published in 2012 and 2015, to date investigate the association between CS and BMI in offspring, considering overall the period of childhood, adolescence, and to some extent adulthood [14, 15]. A recent meta-analysis (2014) found a strong association between CS and increased BMI of offspring's adulthood, reporting a mean increase of $0.44 \mathrm{~kg} / \mathrm{m} 2$ in BMI of adults born by CS (95\% CI: 0.17, 0.72; P = 0.002; I2 = 39\%) [16] whereas a recent (2015) systematic review found a slight influence between CS and the risk of overweight and obesity, which changes with age [17]. A recent update [18] of the previous review [17], included articles only to 2019, and founding similar results. Since then, several other studies with wider sample sizes and longer follow-up times have been published. Therefore, a systematic review and meta-analysis was conducted to summarize the evidence on the association between CS delivery and offspring BMI in adulthood and to assess the risk of overweight and obesity in offspring's adulthood.

\section{Materials and Methods}

\section{Literature search strategy}

Our literature search was aimed at identifying available research studies that investigated the effects of CS on offspring BMI. We identified the studies included in our meta-analysis by searching, without restrictions, multiple literature databases including Scopus, Web of Knowledge and PubMed, and selecting all the articles published until 2nd January 2021. We searched for abstracts and articles including the following terms: caesarean OR cesarean OR caesarian OR cesarian) AND (obesity OR Body Mass Index OR Overweight) AND (Adult) AND (Offspring). In addition, we supplemented this research by checking the references cited in retrieved papers and recent reviews.

\section{Data extraction}

We systematically reviewed and selected the studies meeting the following eligibility criteria: (I) assessed both mode of delivery and adult ( $\geq 18$ years) offspring BMI, (II) used a cohort or case-control study design and (III) reported a risk estimate (hazard ratio, relative risk, prevalence ratio or OR) for the association between mode of delivery and BMI, as well as its $95 \%$ CI. When studies reported data from the same population, only the most comprehensive study was enrolled. Studies providing insufficient or overlapping data and conference abstract were excluded. Two investigators (M. C and B. DS) reviewed the eligibility of all studies according to the predetermined eligibility criteria independently. We extracted information about study characteristics (study name, authors, publication year, study design), study population characteristics, type of exposure (mode of delivery), outcomes (BMI...), and variables of adjustment. The mode of delivery was categorized in vaginal delivery (VD), as reference (including natural, forceps and vacuum extraction), and cesarean section (CS) including Planned CS (elective) and non-planned CS (non-elective). The outcomes of interest in our analysis were overweight and obesity classified according to the International Classification of BMI [19], namely 'overweight" (BMI=25.029.9) and "obese" (BMI $\geq 30)$.

\section{Quality Evaluation}


We used the Newcastle-Ottawa Scale Assessment [20] for the evaluation of quality of the enrolled studies. Newcastle-Ottawa Scale adopted a star system scoring from 0 to 9 and a total score $\geq 7$ indicated a high-quality study. Two investigators (B. DS. and I.G.) performed the quality evaluation of each selected study and disagreements were settled by a joint reevaluation of the original article with a third reviewer. No study was excluded based on quality criteria, in order to avoid selection bias.

\section{Statistical Analysis}

We evaluated the association between born by CS and BMI using the statistical program ProMeta version 3.0 (IDo Statistics-Internovi, Cesena, Italy). For the overall estimation, the hazard ratio was taken as an approximation to the OR, and the meta-analysis was performed as if all types of ratios were ORs. The combined risk estimate was calculated using a random-effects model in which the effect measures were ORs or hazard ratio. We assessed heterogeneity between studies by the Cochran's $Q$ statistic $(\chi 2)$, deeming $\mathrm{p}<0.05$ as significant, and I2 test, which yields results ranged from 0 to $100 \%$ (I2 $=0-25 \%$, no heterogeneity; $\mathrm{I} 2=25-50 \%$, moderate heterogeneity; $\mathrm{I} 2=50-75 \%$, large heterogeneity; and $\mathrm{I} 2=$ 75-100\%, extreme heterogeneity) [21]. To explore the sources of heterogeneity among studies and to test the robustness of the associations, we conducted subgroup analyses and sensitivity analyses. We further examined the influence of individual studies on the overall risk estimate, which was investigated by recalculating the pooled estimates for the remainder of the studies by omitting one study at each turn. Publication bias was evaluated using the methods of Begg and Mazumdar [22] and Egger et al. [23] (, which both test for funnel plot asymmetry, the former based on the rank correlation between the effect estimates and their sampling variances, and the latter based on a linear regression of a standard normal deviate on its precision. If the intercept of Egger's regression line deviated from zero with a $\mathrm{p}$ value $<0.10$, the funnel plot was considered asymmetrical. In case of a small number ( 25 or fewer) of studies enrolled in the meta-analysis, as in the current review, this test for asymmetry possesses relatively low power to detect a real publication bias. If a potential bias was detected, sensitivity analyses were performed to assess the robustness of our findings. $p$ values reported are from 2 -sided statistical tests and differences with $\mathrm{p}<0.05$ were considered significant. This review is reported according to Metaanalysis Of Observational Studies in Epidemiology (MOOSE) [24] and Preferred Reporting Items for Systematic Reviews and Meta-Analyses (PRISMA) guidelines [25].

\section{Results}

\section{Study profiles}

The study selection process is shown in Figure 1. Our initial research returned 316 citations. After excluding 142 duplicates, the analysis of titles and abstracts identified 10 studies on the potential association of CS with offspring BMI. Through the reference lists of recent relevant reviews and already selected articles, 5 additional articles were included for the analysis. From the 15 potentially eligible articles, 4 studies were excluded from the analysis after the full-text assessment, as follows (Fig. 1):

- 2 studies report overlapping data

- 1 study is an abstract conference

- 1 study reports no risk estimate

Eleven studies with a combined population of 180.408 subjects were included in the metaanalysis. 
Figure 1: Flow diagram of the systematic literature search on birth by Cesarean Section (CS) and offspring overweight/obesity.

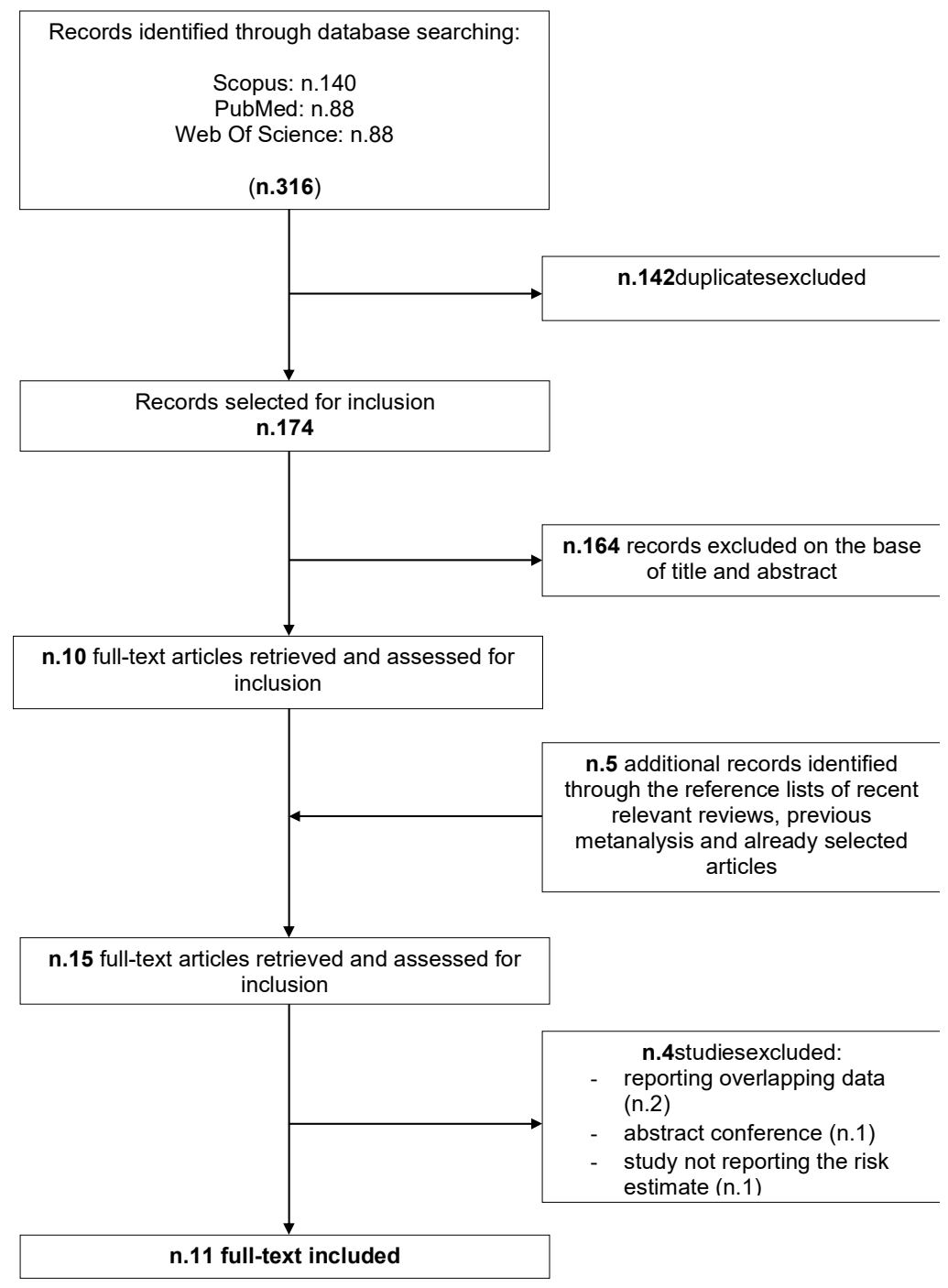

\section{Study Characteristics}

The detailed characteristics of included studies are summarized in Table 1.

Table 1: Main characteristics of studies included in the systematic review and meta-analysis on birth by Cesarean Section (CS) and offspring overweight/obesity. 
TABLE 1. Main characteristics of studies included in the systematic review and meta-analysis on birth by Cesarean Section (CS) and offspring overweight/obesity.

\begin{tabular}{|c|c|c|c|c|c|c|c|}
\hline $\begin{array}{c}\text { First author } \\
\text { Year } \\
\text { Country of } \\
\text { study }\end{array}$ & $\begin{array}{c}\text { Study design } \\
\text { name and } \\
\text { population } \\
\text { Follow-up } \\
\text { Age }\end{array}$ & $\begin{array}{c}\text { Identification of } \\
\text { cases }\end{array}$ & $\begin{array}{l}\text { Exposure } \\
\text { assessment }\end{array}$ & $\begin{array}{c}\text { Outcome } \\
\text { OFFSPRING }\end{array}$ & $\begin{array}{c}\text { OR/RR/PR } \\
(95 \% \mathrm{CI})\end{array}$ & $\begin{array}{c}\text { Matched or } \\
\text { adjusted } \\
\text { variables }\end{array}$ & $\begin{array}{l}\text { Quality } \\
\text { Score } \\
\text { (NOS) }\end{array}$ \\
\hline $\begin{array}{l}\text { Ahlqvist VH et } \\
\text { al (29) }\end{array}$ & $\begin{array}{l}\text { Cohort study } \\
\text { Population: } \mathrm{n} \text {. } \\
97291 \text { males } \\
\text { born between } \\
1982 \text { and } 1987 \\
\text { Follow-up: } 18 \mathrm{y}\end{array}$ & $\begin{array}{l}\text { Weight }(\mathrm{kg}) \text { and } \\
\text { height }(\mathrm{cm}) \\
\text { using a } \\
\text { standardized } \\
\text { scale and a } \\
\text { stadiometer } \\
\text { under } \\
\text { supervision of a } \\
\text { nurse or } \\
\text { physician }\end{array}$ & $\begin{array}{l}\text { Using the } \\
\text { Swedish Medical } \\
\text { Birth Register, } \\
\text { we obtained } \\
\text { information on } \\
\text { recorded mode } \\
\text { of delivery } \\
\text { (vaginal or } \\
\text { cesarean } \\
\text { delivery), which } \\
\text { was } \\
\text { supplemented } \\
\text { with information } \\
\text { on indication for } \\
\text { cesarean } \\
\text { delivery (elective } \\
\text { or nonelective) }\end{array}$ & 更 & $\begin{array}{l}\text { RR } \\
\text { VD*: Ref } \\
\text { CS elective: } 0.99(0.90- \\
1.08) \\
\text { CS non elective: } \\
0.99(0.90-1.08) \\
\text { VD: Ref } \\
\text { CS elective: } 1.02(0.88- \\
1.18) \\
\text { CS non elective: } \\
0.96(0.83-1.10)\end{array}$ & $\begin{array}{l}\text { Adjusted for } \\
\text { MATERNAL } \\
\text { Age at } \\
\text { delivery, } \\
\text { education, } \\
\text { smoking, } \\
\text { parity, Pre- } \\
\text { pregnancy } \\
\text { BMI, diabetes } \\
\text { at delivery, } \\
\text { hypertension at } \\
\text { delivery, } \\
\text { OFFSPRING: } \\
\text { birth weight } \\
\text { standardized } \\
\text { according to } \\
\text { gestational age, } \\
\text { preeclampsia, } \\
\text { and gestational } \\
\text { age. }\end{array}$ & 6 \\
\hline $\begin{array}{l}\text { Goldani } \mathrm{H} \text { et al } \\
\text { (30) }\end{array}$ & $\begin{array}{l}\text { Cohort study } \\
\text { Population: n. } \\
2057 \text { subjects } \\
\text { born from } 1 \text { June } \\
1978 \\
\text { to } 31 \text { May } 1979 .\end{array}$ & $\begin{array}{l}\text { physical } \\
\text { examination for } \\
\text { anthropometric } \\
\text { assessment and } \\
\text { lifestyle } \\
\text { questionnaire } \\
\text { and a } \\
\text { socioeconomic } \\
\text { questionnaire }\end{array}$ & $\begin{array}{l}\text { Trained } \\
\text { personnel } \\
\text { collected data } \\
\text { from mothers } \\
\text { and children at } \\
\text { the time of birth. }\end{array}$ & Obesity & $\begin{array}{l}\text { VD: Ref } \\
\text { CS: } 1.58(1.23,2.02)\end{array}$ & $\begin{array}{l}\text { OFFSPRING: } \\
\text { birth weight, } \\
\text { sex, physical } \\
\text { activity, } \\
\text { smoking, } \\
\text { schooling, and } \\
\text { income }\end{array}$ & 9 \\
\hline
\end{tabular}




\begin{tabular}{|c|c|c|c|c|c|c|c|}
\hline $\begin{array}{l}\text { Rooney B et al } \\
\text { (31) } \\
2011 \\
\text { United States }\end{array}$ & $\begin{array}{l}\text { Cohort study } \\
\text { Population: } n \text {. } \\
453 \text { subjects } \\
\text { between } 18-20 \text { y } \\
\text { Follow-up: } 20 \text { y } \\
\text { Age: } 18-20 \text { y }\end{array}$ & $\begin{array}{l}\text { Weight and } \\
\text { height } \\
\text { measurements } \\
\text { available at any } \\
\text { time } \\
\text { during } \\
\text { adolescence } \\
\text { (ages 9-14 } \\
\text { years) and at the } \\
\text { offspring's } \\
\text { last appointment } \\
\text { (ages 18-20 } \\
\text { years) were also } \\
\text { gathered }\end{array}$ & $\begin{array}{l}\text { Offspring data } \\
\text { were obtained } \\
\text { through medical } \\
\text { record review. }\end{array}$ & Obesity & $\begin{array}{l}\text { VD: Ref } \\
\text { CS: } 2.78(1.30,5.94)\end{array}$ & Not adjusted & 4 \\
\hline $\begin{array}{l}\text { Barros FC et al } \\
\text { (32) }\end{array}$ & $\begin{array}{l}\text { Cohort study } \\
\text { Population: } 4297 \\
\text { subjects from } \\
1982 \\
\text { Follow-up: } 23 \text { y } \\
\text { Age: mean } 22.8 \\
\text { y (21.9-23.7y) }\end{array}$ & $\begin{array}{l}\text { All individuals } \\
\text { were weighed } \\
\text { and measured } \\
\text { with } \\
\text { standardized } \\
\text { techniques }\end{array}$ & $\begin{array}{l}\text { Mothers were } \\
\text { interviewed } \\
\text { by using a } \\
\text { pretested } \\
\text { structured } \\
\text { questionnaire }\end{array}$ & $\begin{array}{l}\text { Male obesity } \\
\text { Female } \\
\text { obesity }\end{array}$ & $\begin{array}{l}\text { PR } \\
\text { VD: Ref } \\
\text { CS: } 1.10(0.87-1.41) \\
\text { VD: Ref } \\
\text { CS: } 0.94(0.60-1.31) \\
\text { VD: Ref } \\
\text { CS: } 1.33(0.94-189)\end{array}$ & $\begin{array}{l}\text { Adjusted for } \\
\text { MATERNAL: } \\
\text { Age, education, } \\
\text { smoking } \\
\text { pre-pregnancy } \\
\text { BMI, type of } \\
\text { payment for } \\
\text { delivery } \\
\text { OFFSPRING: } \\
\text { family income } \\
\text { at birth, skin } \\
\text { color, birth } \\
\text { order, birth } \\
\text { weight, } \\
\text { schooling, } \\
\text { physical } \\
\text { activity, } \\
\text { smoking and } \\
\text { alcohol } \\
\text { consumption }\end{array}$ & 8 \\
\hline $\begin{array}{l}\text { Mamun A et al. } \\
\text { (33) }\end{array}$ & $\begin{array}{l}\text { Cohort study } \\
\text { Population: } n \text {. } \\
2625 \text { subjects } \\
\text { born between } \\
1981 \text { and } 1983\end{array}$ & $\begin{array}{l}\text { Detailed physical } \\
\text { and } \\
\text { developmental } \\
\text { examinations }\end{array}$ & $\begin{array}{l}\text { hospital records } \\
\text { mode of delivery }\end{array}$ & Overweight & $\begin{array}{l}\text { VD: Ref } \\
\text { CS: } 0.9(0.6-1.2) \\
\text { VD: Ref }\end{array}$ & $\begin{array}{l}\text { MATERNAL: } \\
\text { age at delivery, } \\
\text { race, education, } \\
\text { smoking during }\end{array}$ & 7 \\
\hline
\end{tabular}




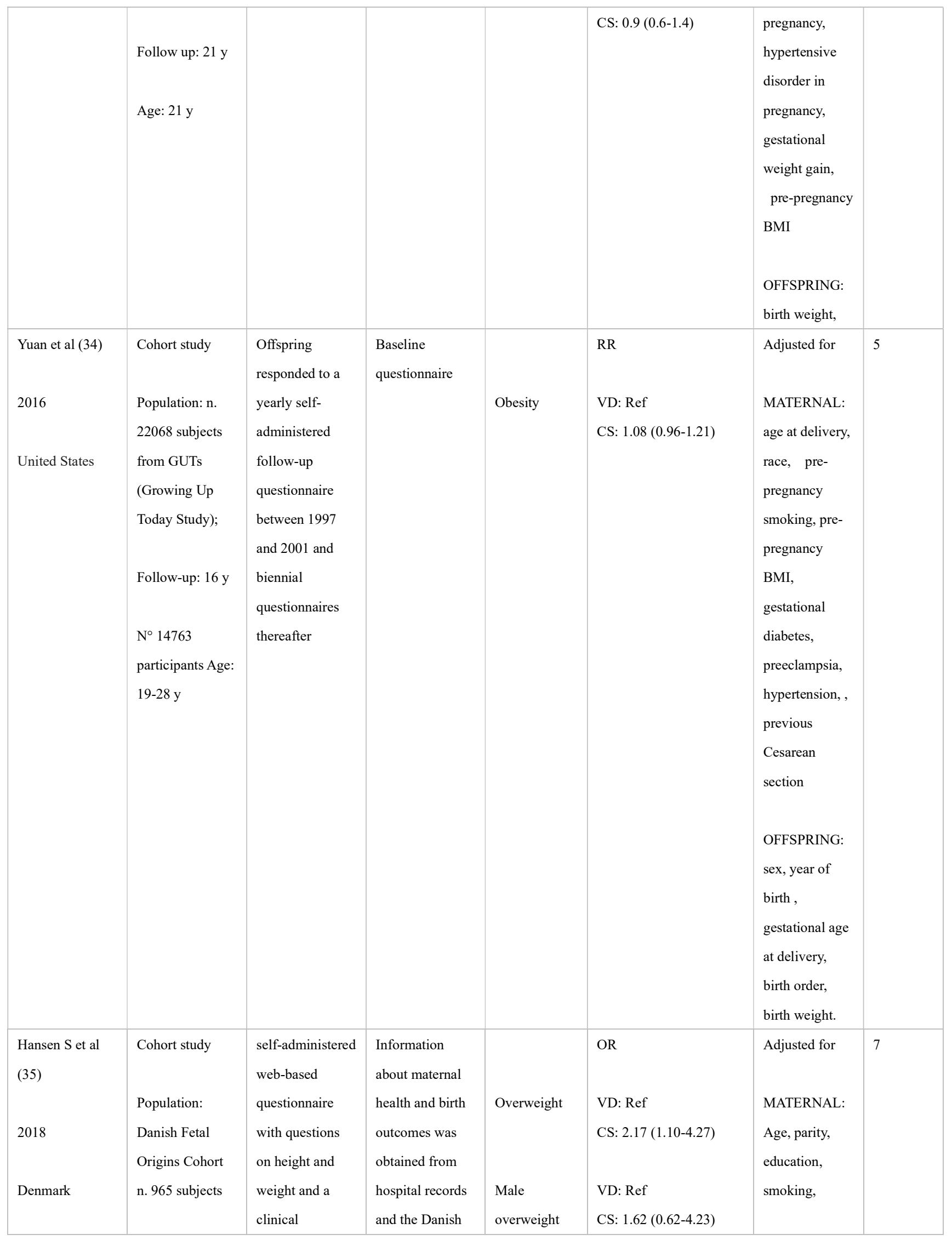




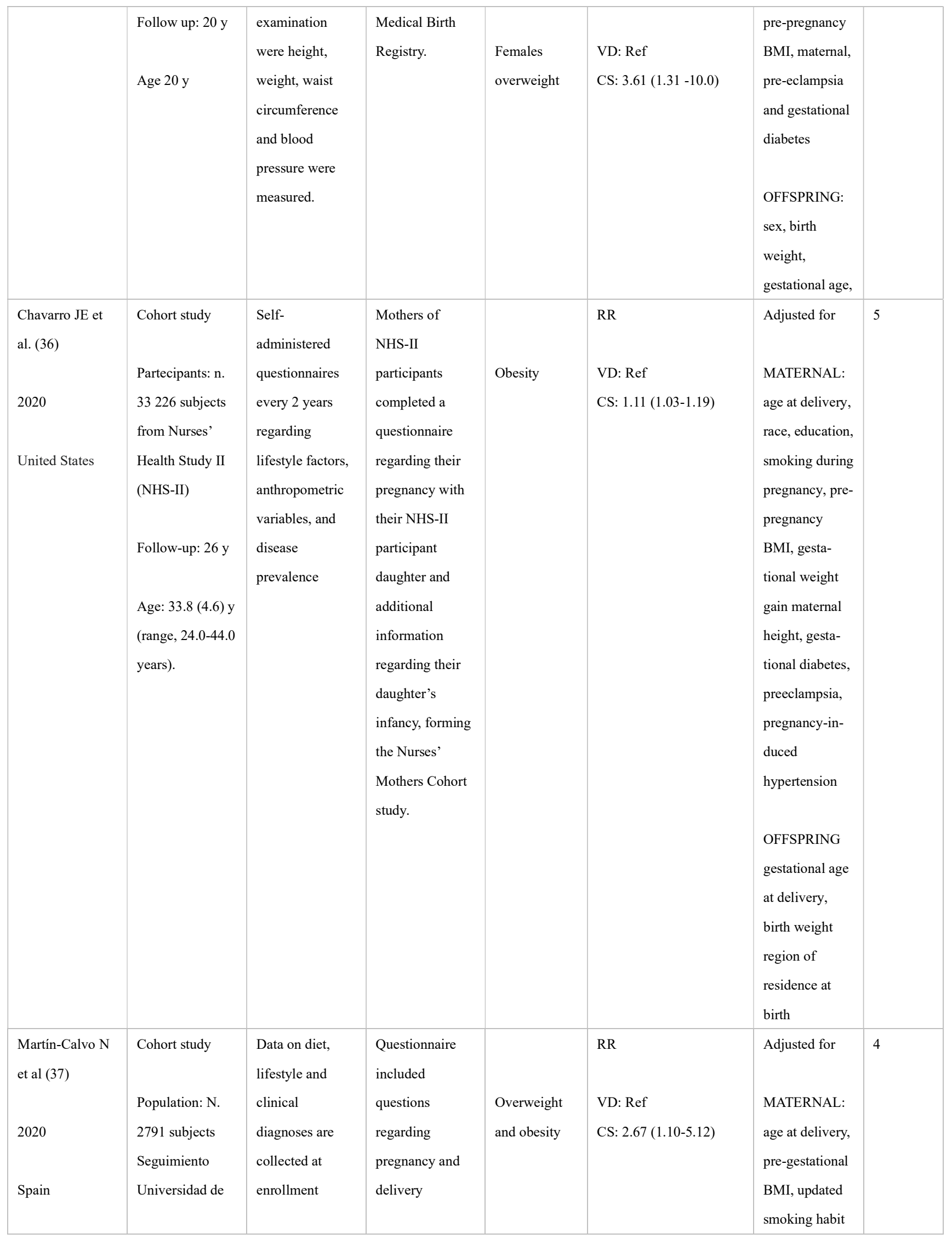




\begin{tabular}{|c|c|c|c|c|c|c|c|}
\hline & $\begin{array}{l}\text { Navarra (SUN) } \\
\text { cohort. } \\
\text { Follow-up: } 18 \text { y } \\
\text { Age: } 18 \text { y }\end{array}$ & $\begin{array}{l}\text { (baseline) and } \\
\text { every } 2 \text { years. }\end{array}$ & & 更 & $\begin{array}{l}\text { VD: Ref } \\
\text { CS: } 1.71(1.10-2.52) \\
\text { VD: Ref } \\
\text { CS: } 2.48(1.39-4.16)\end{array}$ & $\begin{array}{l}\text { OFFSPRING } \\
\text { Age, sex, } \\
\text { gestational age } \\
\text { and birth } \\
\text { weight } \\
\text { Not adjusted } \\
\text { Not adjusted }\end{array}$ & \\
\hline $\begin{array}{l}\text { Sogunle E et al } \\
\text { (38) } \\
2019\end{array}$ & $\begin{array}{l}\text { Case/Control } \\
\text { Study } \\
\text { Partecipants } 889 \\
\text { subjects from the } \\
\text { prospective } \\
\text { South African } \\
\text { birth cohort } \\
\text { (Birth to Twenty } \\
\text { Plus 1990) } \\
\text { Follow-up: } 24 \text { y } \\
\text { Age 21-24 y }\end{array}$ & $\begin{array}{l}\text { Administered } \\
\text { questionnaires, } \\
\text { contact with } \\
\text { parents or } \\
\text { caregivers, } \\
\text { telephone calls, } \\
\text { and field visits. } \\
\text { measurements } \\
\text { were } \\
\text { taken by trained } \\
\text { research } \\
\text { personnel. }\end{array}$ & $\begin{array}{l}\text { Information on } \\
\text { mode of delivery } \\
\text { was copied by } \\
\text { the investigators } \\
\text { of the South } \\
\text { African birth } \\
\text { cohort from the } \\
\text { official birth } \\
\text { notification } \\
\text { forms compiled } \\
\text { at the local } \\
\text { authority. }\end{array}$ & Males obesity & $\begin{array}{l}\text { OR } \\
\text { VD: Ref } \\
\text { CS: } 1.64(1.01-2.68) \\
\text { VD: Ref } \\
\text { CS: 4.01(1.14-14.09) } \\
\text { VD: Ref } \\
\text { CS: } 1.44(0.85-2.44)\end{array}$ & $\begin{array}{l}\text { Adjusted for } \\
\text { MATERNAL: } \\
\text { education and } \\
\text { parity } \\
\text { OFFSPRING } \\
\text { sex and birth } \\
\text { weight; }\end{array}$ & 7 \\
\hline $\begin{array}{l}\text { Svensson E et al } \\
\text { (39) } \\
2013\end{array}$ & $\begin{array}{l}\text { Case/Control } \\
\text { Study } \\
\text { Population: } \\
21051 \text { Danish } \\
\text { men born in } \\
\text { 1977-1983 }\end{array}$ & $\begin{array}{l}\text { Height and } \\
\text { weight measured } \\
\text { to calculate BMI }\end{array}$ & $\begin{array}{l}\text { Medical Birth } \\
\text { Registry, Danish } \\
\text { National } \\
\text { Registry of } \\
\text { Patients }\end{array}$ & Overweight & $\begin{array}{l}\text { PR } \\
\text { VD: Ref } \\
\text { CS: } 1.05 \text { (0.94-1.17) } \\
\text { Non planned CS: } 0.95 \\
(0.75-1.21) \\
\text { Planned CS: } 1.09 \text { (0.81- } \\
\text { 1.48) } \\
\text { VD: Ref } \\
\text { CS: } 1.35 \text { (1.14-1.59) } \\
\text { Non planned CS: } 1.32 \\
\text { (0.93-1.87) } \\
\text { Planned CS: } 1.49 \text { (0.94- } \\
\text { 2.36) }\end{array}$ & $\begin{array}{l}\text { Adjusted for } \\
\text { MATERNAL: } \\
\text { Age, marital } \\
\text { status, parity, } \\
\text { diabetes, } \\
\text { gestational } \\
\text { hypertensive } \\
\text { disorder, } \\
\text { hospitalization } \\
\text { for infection } \\
\text { during } \\
\text { pregnancy }\end{array}$ & 8 \\
\hline
\end{tabular}


In our selection, 9 studies $[29,30,31,32,33,34,35,36,37]$ have prospective study design and two studies have retrospective study design [38, 39]. Two studies reported subtype of CS (Elective CS and Non elective CS) [29,39], four studies investigated the association of CS with overweight and obesity [29, 33, 37, 39], one the association of CS with overweight [35] and six the association of CS with obesity [30, 31, 32, 34, 36, 38]. Four studies were conducted in Europe (in particular, two in Denmark [35,39], one in Spain [37], one in Sweden [29]), 3 studies in USA [31, 34, 36], 2 studies in south America (Brazil) [30, 32], one in Australia [33] and the remaining one in Africa (South Africa) [38]. Five studies reported $R R(29,31,34,36,37)$, three reported $\mathrm{OR}(33,35,38)$ and three reported $\mathrm{PR}(30,32$, 39). Among the studies, five reported overall risk estimates in offspring [30, 31, 33, 34, 37], one study reported risk estimates for females' sex only [36] and two studies for males' sex only [29, 39], while the three studies reported risk estimates for both sexes [32, 35, 38]. Four studies investigated the risk of overweight in adults aged 18-20 years [29, 35, 37, 39] and one study in adults aged 21 or more years [33]. Obesity was the outcome of interest in four studies investigating adults aged $18-20$ years $[29,31,37,39]$ and five studies investigating adults aged 21 or more years [ $30,32,36,38,39]$.

\section{Quality Assessment}

The range of quality score was from 4 to 9 (median: 7). High-quality studies (i.e., those studies that had a score $\geq 7$ ) included 2 case-control $[38,39]$ and 4 cohort studies [30, 32, $34,35]$.

\section{Meta-Analyses}

The overall analysis of the 11 studies $(n=18)$ yielded a combined risk estimate for overweight/obesity of 1.19 (95\% CI 1.08-1.31) and the test of heterogeneity resulted $\mathrm{Q}=53,37$ (I2 $=70,37 \%, \mathrm{P} \leq 0 \cdot 0001)$.

The forest plots are shown in Figure 2.

Figure 2: Forest plots of the association between Cesarean Section and offspring "Overweight" (A) and "Obesity" (B). ES, effect size.

A:

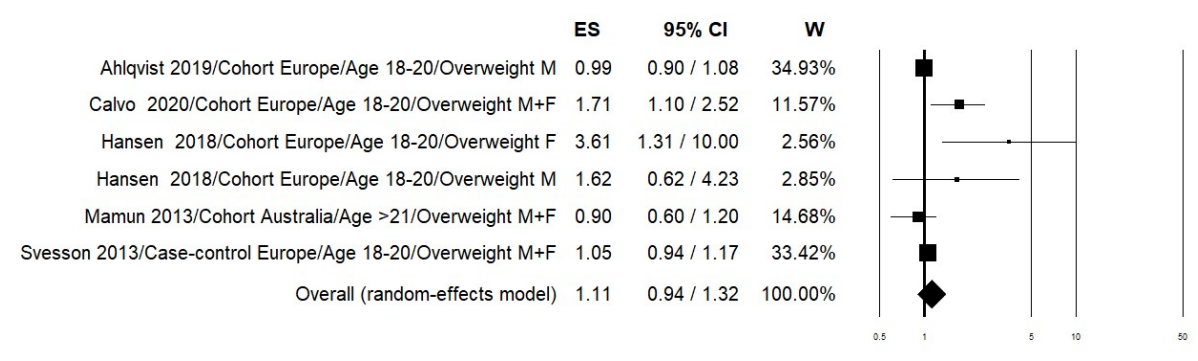

B: 


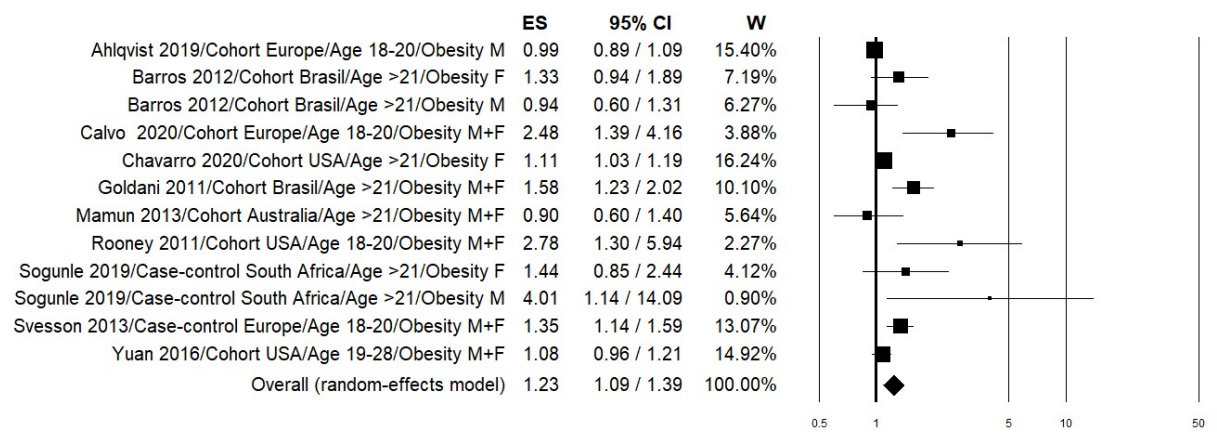

Further analyses were performed stratifying by study design, sex, age, geographic area and level of BMI (Overweight/Obesity) (Table 2).

Table 2: Results of overall analysis and stratified analysis of the "Overweight" and "Obesity" risk estimates for the Birth by cesarean section.

\begin{tabular}{|c|c|c|c|c|c|c|c|}
\hline & \multicolumn{2}{|c|}{ Combined risk estimate } & \multicolumn{3}{|c|}{ Test of heterogeneity } & \multicolumn{2}{|c|}{ Publication bias } \\
\hline & Value $(95 \% \mathrm{Cl})$ & $\mathbf{p}$ & $\mathbf{Q}$ & $I^{2} \%$ & $\mathbf{p}$ & $\begin{array}{l}p \\
\text { (Egger test) }\end{array}$ & $\begin{array}{l}p \\
\text { (Begg test) }\end{array}$ \\
\hline All $(n=18)$ & $1.19(1.08-1.31)$ & 0.0004 & 53.37 & 70.37 & $<0.0001$ & 0.005 & 0.063 \\
\hline Study Profile & & & & & & & \\
\hline Case Control $(n=4)$ & $1.27(0.99-1.64)$ & 0.058 & 10.71 & 71.99 & 0.013 & 0.208 & 0.497 \\
\hline Cohort $(n=14)$ & $1.17(1.05-1.31)$ & 0.04 & 45.16 & 71.21 & $<0.0001$ & 0.028 & 0.090 \\
\hline Sex & & & & & & & \\
\hline Male $(n=5)$ & $1.00(0.90-1.11)$ & 0.968 & 5.81 & 31.20 & 0.213 & 0.140 & 0.142 \\
\hline Female $(n=4)$ & $1.32(1.00-1.75)$ & 0.051 & 6.90 & 56.53 & 0.075 & 0.063 & 0.174 \\
\hline Age & & & & & & & \\
\hline Age $>20(n=8)$ & $1.18(0.99-1.40)$ & 0.062 & 16.41 & 57.34 & 0.022 & 0.450 & 0.458 \\
\hline Age $18-20(n=9)$ & $1.27(1.08-1.49)$ & 0.004 & 38.88 & 79.42 & $<0.0001$ & 0.002 & 0.095 \\
\hline Geopraphic Area & & & & & & & \\
\hline Europe $(n=8)$ & $1.22(1.04-1.42)$ & 0.012 & 32.74 & 78.62 & $<0.0001$ & 0.006 & 0.048 \\
\hline USA $(n=3)$ & $1.13(0.98-1.31)$ & 0.094 & 5.82 & 65.65 & 0.054 & 0.324 & 0.602 \\
\hline Brazil $(n=3)$ & $1.29(0.96-1.73)$ & 0.086 & 4.85 & 58.80 & 0.088 & 0.253 & 0.117 \\
\hline Level of BMI & & & & & & & \\
\hline Overweight $(n=6)$ & $1.11(0.94-1.32)$ & 0.217 & 13.87 & 63.96 & 0.0160 & 0.098 & 0.091 \\
\hline Obesity $(n=12)$ & $1.23(1.09-1.39)$ & 0.001 & 39.50 & 72.15 & $<0.0001$ & 0.032 & 0.217 \\
\hline Overweight $(n=6)$ & $1.11(0.94-1.32)$ & 0.217 & 13.87 & 63.96 & 0.0160 & 0.098 & 0.091 \\
\hline Case-Control $(n=1)$ & $1.05(0.94-1.17)$ & 0.382 & & & & & \\
\hline Cohort $(n=5)$ & $1.28(0.91-1.79)$ & 0.156 & 13.72 & 70.84 & $<0.0001$ & 0.142 & 0.142 \\
\hline Male $(n=2)$ & $0.99(0.90-1.09)$ & 0.914 & 1.00 & 0.17 & 0.317 & & \\
\hline Female $(n=1)$ & $3.61(1.31-10.0)$ & 0.013 & & & & & \\
\hline Age $>20 \quad(n=1)$ & $0.90(0.60-1.20)$ & 0.551 & & & & & \\
\hline Age $18-20(n=5)$ & $1.16(0.96-1.41)$ & 0.120 & 13.25 & 69.82 & 0.010 & 0.029 & 0.050 \\
\hline
\end{tabular}




\begin{tabular}{|c|c|c|c|c|c|c|c|}
\hline $\begin{array}{l}\text { Europe }(n=5) \\
\text { USA }(n=0) \\
\text { Brazil }(n=0)\end{array}$ & $1.16(0.96-1.41)$ & 0.120 & 13.25 & 69.82 & 0.010 & 0.029 & 0.050 \\
\hline Obesity (n=12) & $1.23(1.09-1.39)$ & 0.001 & 39.50 & 72.15 & $<0.0001$ & 0.032 & 0.217 \\
\hline Case-Control $(n=3)$ & $1.46(1.07-1.99)$ & 0.017 & 2.86 & 30.01 & 0.240 & 0.336 & 0.117 \\
\hline Cohort $(n=9)$ & $1.18(1.04-1.35)$ & 0.011 & 29.29 & 72.68 & 0.008 & 0.132 & 0.532 \\
\hline Male $(n=3)$ & $1.07(0.75-1.53)$ & 0.697 & 4.81 & 58.44 & 0.090 & 0.501 & 0.117 \\
\hline Female $(n=3)$ & $1.12(1.05-1.20)$ & 0.001 & 1.86 & 0.00 & 0.395 & 0.043 & 0.602 \\
\hline Age $>20(n=7)$ & $1.23(1.02-1.48)$ & 0.034 & 14.65 & 59.05 & 0.023 & 0.290 & 0.652 \\
\hline Age $18-20(n=4)$ & $1.50(1.06-2.13)$ & 0.024 & 24.09 & 87.54 & $<0.0001$ & 0.087 & 0.497 \\
\hline Europe $(n=3)$ & $1.35(0.95-1.91)$ & 0.091 & 18.42 & 89.14 & $<0.0001$ & 0.259 & 0.117 \\
\hline USA $(n=3)$ & $1.13(0.98-1.31)$ & 0.094 & 5.82 & 65.65 & 0.054 & 0.324 & 0.602 \\
\hline Brazil $(n=3)$ & $1.29(0.96-1.73)$ & 0.086 & 4.85 & 58.80 & 0.088 & 0.253 & 0.117 \\
\hline
\end{tabular}

The results showed a significantly increased risk of overweight/obesity in association with birth by CS in cohort studies, with a risk estimate of 1.17 (95 \% CI 1.05, 1.31; P=0.04). Stratifying by sex a significant association was found in females (OR 1.32; 95\% CI 1.00-1.75), while no significant association was found in males (OR 1.00; 95\% CI 0.90-1.11). CS was associated with a significantly increased risk of overweight/obesity in adults aged 18- 20 years (OR 1.27; 95\% CI 1.08-1.49), but not in adults aged $>20$ years (OR 1.18; 95\% CI 0.991.40). The stratified analysis by geographic area showed a significantly increased risk of overweight/obesity in Europe (OR 1.22; 95\% CI 1.04-1.42) but not in USA (OR 1.13; 95\% CI 0.98-1.31) and Brazil (OR 1.29; 95\% CI 0.96-1.73). Stratifying by BMI values, CS was associated with a significantly higher risk of developing obesity in adulthood (OR 1.23; 95\% CI 1.09-1.39) while no significant effect on overweight (OR 1.11; 95\% CI 0.94-1.32) was observed.

\section{Cesarean birth and overweight offspring}

The overall analysis of the 5 studies pooled together $(n=6)$ yielded a combined risk estimate for overweight of 1.11 (95\% CI 0.94-1.32) and the test of heterogeneity resulted $\mathrm{Q}=13.87(\mathrm{I} 2=63,96 \%, \mathrm{P}=0 \cdot 0160)$. The forest plots are reported in Figure 2.

\section{Cesarean birth and obesity offspring}

The overall analysis of the 10 studies pooled together $(n=12)$ yielded a combined risk estimate for obesity of 1.23 (95\% CI 1.09-1.39) and the test of heterogeneity resulted $\mathrm{Q}=39.50(\mathrm{I} 2=72,15 \%, \mathrm{P} \leq 0 \cdot 0001)$. The forest plots are reported in Figure 2.

A Significant association was found in case control studies (OR 1.46; 95\% CI 1.07-1.99) and in cohort studies (OR 1.18; 95\% CI 1.04-1.35). A Significant association was found in age 18-20 years (OR 1.50; 95\% CI 1.06-2.13), in age >20 years (OR 1.23; 95\% CI 1.02-1.48) and in females (OR 1.12; 95\% CI 1.05-1.20), but not in males (OR 1.00; 95\% CI 0.90-1.11). No significant association was found in different geographical area (Europa, USA, Brazil) Table 2 . 


\section{Publication Bias}

Bias detection revealed a significant effect $(\mathrm{P}=0 \cdot 005)$ using the method of Egger, while no bias was detected by the Begg and Mazumder test ( $\mathrm{P}=0.063$ ) (Figure 3). In the stratified analysis on the association between CS and obesity a significant publication bias was detected by Egger test; $(\mathrm{P}=0.032)$, but not by Begg and Mazumder test; $\mathrm{P}=0.217$ ) The funnel plots of the meta-analyses are shown in figure 3.

Figure 3: Funnel plots of the meta-analyses on the "Overweight" (A) and "Obesity" (B) offspring.

A:

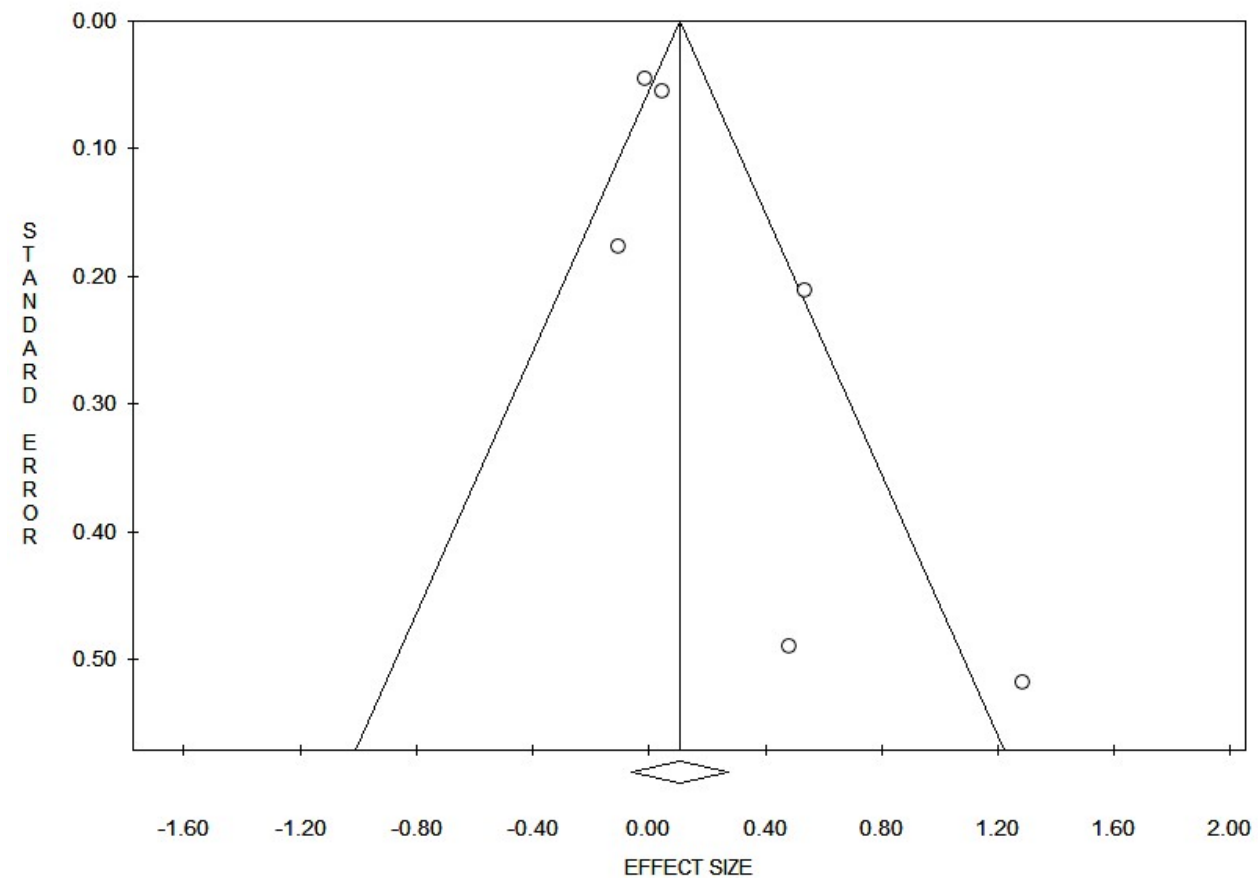

B: 


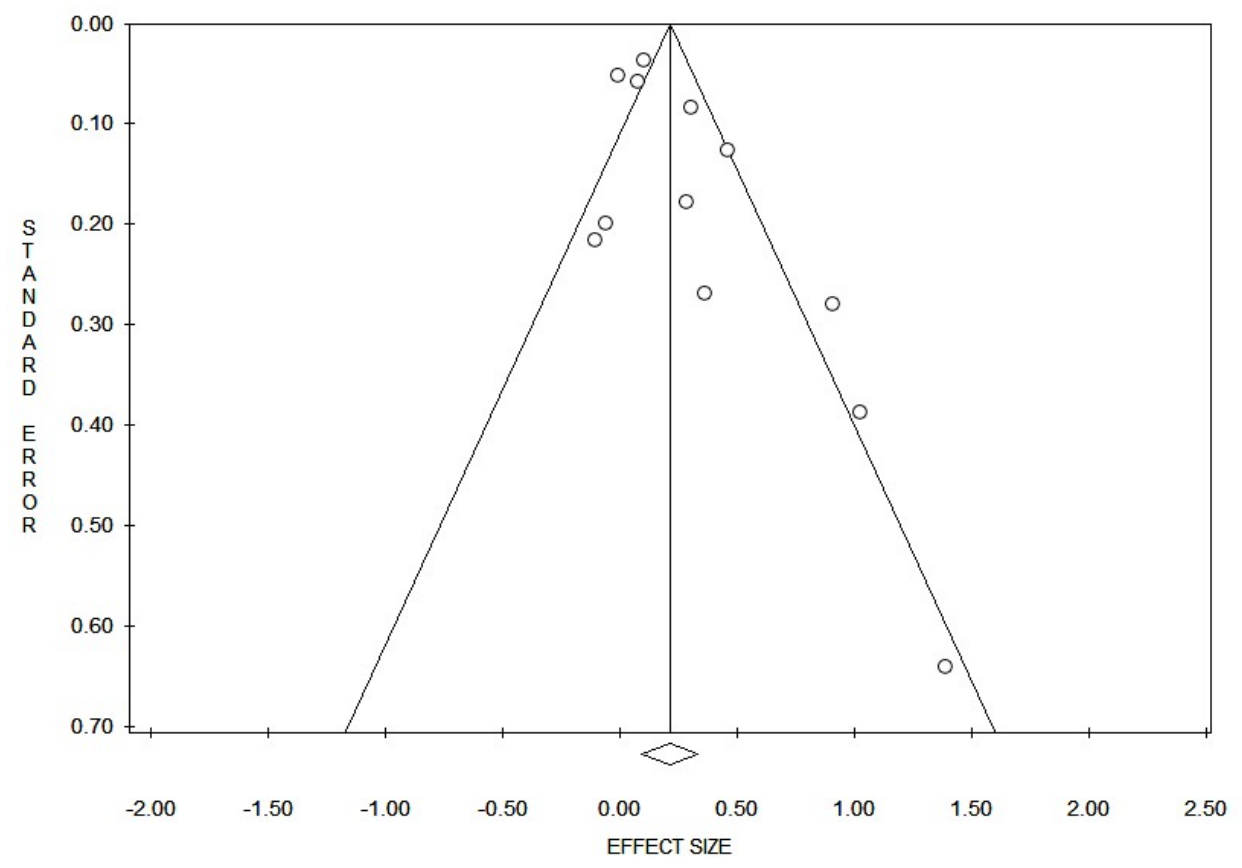

\section{Sensitivity analyses}

Sensitivity analyses by omitting one study in turn suggested that the overall risk estimates were not substantially modified by any single study, with a range from 1.15 (95\% CI 1.051.27 ) to 1.22 (95\% CI 1.10-1.35). Heterogeneity was still observed after omitting each study in turn.

\section{Discussion}

Several studies confirmed that CS is related to different hormonal, physical and bacterial exposures and that this fact can change neonatal physiology and health outcomes [8-13]. Recently, the relationship between CS and offspring's BMI has attracted a great deal of attention. Therefore, we conducted a systematic review and meta-analysis to summarize the evidence on the association between mode of birth and BMI in offspring's adulthood and to assess the risk of obesity and overweight in offspring's adulthood associated with CS. The overall results of the current meta-analysis indicate that CS was associated with a significantly higher risk $(1.19 ; 95 \%$ CI 1.08-1.31) of overweight/obesity in offspring's adulthood. The overall analysis (population $=180.408$ subjects) showed a statistically significant increase of overweight/obesity risk in the cohort studies, in females, in age group 18-20 and in Europe. In case of obesity, significant effects were observed also in case control study

and age $>21$. Our study shows a decrease in significance of overweight/obesity risk as age increases. The

obesity risk is inversely associated to increasing age groups probably in correlation with the fact that the influence of environmental factors on obesity risk increases. This observation could be because lifestyle and environmental factors such as high food consumption, high sweetened beverages, less activity, television watching that are causative of obesity may have assumed greater importance [40]. This may be that the association between CS and overweight/obesity risk factors is more pronounced in prosperous societies, as found in our study with significant results in Europe, where breastfeeding is less common and where there is limited exposure to diverse bacteria in the immediate postnatal period. The underlying causes for obesity are complex, involving social and cultural aspects, and biological context involving epigenetics mechanisms, regulation of food 
intake, and even the gut microbiota [40]. Significant differences have been documented between the microbiome of infants born by caesarean section and infants born vaginally. Such differences were also proven to appear in the gut flora of normal weight people with respect to obese subjects. Children born by CS have similar patterns of intestinal colonization caused by lack of contact with maternal vaginal and intestinal flora [41, 42]. The intestinal flora of infants born through caesarean section is less rich and diverse. Bacterial species protective against later obesity such as Bifidobacteria spp. and Bacteroides, are almost absent and the microbes such as that colonize their gut allows them to harvest more nutrients from diet, this is therefore presumed to persist in adulthood [41, 43]. The mechanism by which CS increases the risk of overweight/obesity could be related to altered epigenetic regulation of obesity gene expression due to higher DNA methylation. CS, in fact, affects epigenetic activity in newborn infants who exhibited a higher DNAmethylation than infants vaginally born [44], on the other hand a higher DNA methylation may be associated to higher risk of overweight and obesity. The mechanism by which CS increases the risk of overweight/obesity could be related to lower rate of breastfeeding in children born by CS. The prevalence of obesity is significantly lower in breastfed people and breastfeeding is associated with a reduction in obesity risk [45]. Similarly to our study, previous meta-analyses found an increased risk of overweight/obesity in offspring's adulthood in association with CS [14, 16, 17, 18], combined risk estimate for obesity/overweight of 1.19 (95\% CI 1.08-1.31), lower compared to the results of previous meta-analyses. These discrepancies are likely due to the inclusion of more recent studies and to the increased population in study, which contributed to improve the precision and reliability of our risk estimates. Indeed, the meta-analysis by Li et al. was published with only three study included reporting a risk of $1.50(1.02,2.20)$ [14] and the meta-analysis by Sultharsan et al considered only a population of 30200 subjects reporting a risk of 1.28 (95\% CI 1.02, 1.34) [17]. On the other hand, the recent meta-analysis by Quecke [18] does not consider recent studies $[36,37]$ which enrolled about 36000 subjects, and, moreover, reported a risk of obesity of 1.22 (IC 25\% 1.02-1.46), while the RR of out meta-analysis is 1.23 (1.09-1.39), with a smaller interval of confidence. Similar to Sutharsan's results, that demonstrated a decreasing effect of overweight/obesity in offspring born by CS across the life stages, our study in age group 18- 20 has overweight/obesity risk of 1.27 (1.08-1.49) and in group age $>20$ have risk of 1.18 (0.99-1.40). Moreover, our finding about the association of CS and obesity 1.23 (95\% CI 1.09-1.39), in contrast with Darmasseelane's results [16]; is stronger than the association of CS and overweight 1.11 (0.94-1.32) The study provides further evidence for CS as a risk factor for obesity in adult offspring and the association between CS and higher risk of overweight/obesity pose a public health concern. The World Health Organization (WHO) recommendations suggest a CS rate lower than 15\% [46] however in developed countries CS rate is higher than recommended and an increasing number of CS have been performed in low-risk pregnancies, without a clear medical indication. Our results reinforce the importance of limiting performing CS for its influence on long term offspring health. In pregnancies with an indication for CS delivery, a greater understanding of the biological mechanism in needed to develop intervention to try to guarantee a microbial colonization like the one of a vaginal delivery and to modify the effect that CS has on obesity. As discussed above, the potential preventive role of early prebiotic or probiotic supplementation, to mimic the intestinal microflora of vaginally delivered infants, on long-lasting health consequences of an altered early life gut microbiota [47], needs to be investigated.

\section{Strengths and Limitations}

Our studies collectively represent a large population of 180,408 subjects, from eight countries, and four different continents. In addition, our review separately assessed the effects of CS on the different categories of BMI (overweight, obesity) in an adult-only population and in the subcategories of sexes and age groups. Our study is the fifth metaanalysis about the relation between CS delivery and overweight/ obesity in offspring 
adults, but it is the only one that have tried to study some subgroups, such as geographical area.

The studies limitations are the small number of studies included, the few risks estimated considered and the failure to investigate how much environmental factors affect obesity risk by age. Furthermore, the prevalence of CS is strongly and directly related to socioeconomic position, residual confounding may affect associations with any outcomes that also vary according to wealth. In any case the control of potential confounders is of considerable importance in studies investigating the association of C-section and obesity.

Author Contributions: All authors have contributed significantly. Author C.M., DS B. and G. I. provided the idea, designed the study, collected the data and wrote the article. Author F.R. collected the data, analyzed the data, modified the article and edited the pictures. Author G.I. performed reference collection. All authors revised the manuscript and approved the final version. All authors are included in the author list and that all are aware that the manuscript was submitted. All authors have declared no competing interests. I confirm my personal full access to all aspects of the research and writing process, and taking final responsibility for the paper.

Funding: This research received no external funding

Informed Consent Statement: Not applicable.

Conflicts of Interest: The authors declare no conflict of interest.

\section{References}

1. NCD Risk Factor Collaboration (NCD-RisC). Trends in adult body-mass index in 200 countries from 1975 to 2014: a pooled analysis of 1698 population-based measurement studies with $19 \cdot 2$ million participants. Lancet. 2016 Apr 2;387(10026):1377-1396. doi: 10.1016/S0140-6736(16)30054-X. Erratum in: Lancet. 2016 May 14;387(10032):1998. PMID: 27115820.

2. Blüher M. Obesity: global epidemiology and pathogenesis. Nat Rev Endocrinol. 2019 May;15(5):288-298. doi: 10.1038/s41574-019-0176-8. PMID: 30814686.

3. Ward ZJ, Bleich SN, Cradock AL et al. Projected U.S. State-Level Prevalence of Adult Obesity and Severe Obesity. N Engl J Med. 2019 Dec 19;381(25):2440-2450. doi: 10.1056/NEJMsa1909301. PMID: 31851800.

4. World Health Organization. Obesity and Overweight. WHO https://www.who.int/mediacentre/factsheets/fs311/en/

5. World Health Organization. Noncommunicable diseases progress monitor, $2017 . \quad$ WHO https://www.who.int/nmh/publications/ncd-progress-monitor-2017/en/

6. GBD 2015 Risk Factors Collaborators. Global, regional, and national comparative risk assessment of 79 behavioural, environmental and occupational, and metabolic risks or clusters of risks, 1990-2015: a systematic analysis for the Global Burden of Disease Study 2015. Lancet. 2016 Oct 8;388(10053):1659-1724. doi: 10.1016/S0140-6736(16)31679-8. Erratum in: Lancet. 2017 Jan 7;389(10064):e1. PMID: 27733284; PMCID: PMC5388856.

7. Boerma T, Ronsmans C, Melesse DY et al. Global epidemiology of use of and disparities in caesarean sections. Lancet. 2018 Oct 13;392(10155):1341-1348. doi: 10.1016/S0140-6736(18)31928-7. PMID: 30322584.

8. Sandall J, Tribe RM, Avery L et al. Short-term and long-term effects of caesarean section on the health of women and children. Lancet. 2018 Oct 13;392(10155):1349-1357. doi: 10.1016/S0140-6736(18)31930-5. PMID: 30322585.

9. Bager P, Wohlfahrt J, Westergaard T. Caesarean delivery and risk of atopy and allergic disease: meta-analyses. Clin Exp Allergy. 2008 Apr;38(4):634-42. doi: 10.1111/j.1365-2222.2008.02939.x. Epub 2008 Feb 11. PMID: 18266879. 
10. Thavagnanam S, Fleming J, Bromley A, Shields MD, Cardwell CR. A meta-analysis of the association between Caesarean section and childhood asthma. Clin Exp Allergy. 2008 Apr;38(4):629-33. doi: 10.1111/j.13652222.2007.02780.x. PMID: 18352976.

11. Decker E, Engelmann G, Findeisen A et al. Cesarean delivery is associated with celiac disease but not inflammatory bowel disease in children. Pediatrics. 2010 Jun;125(6):e1433-40. Doi: 10.1542/peds.2009-2260. Epub 2010 May 17. PMID: 20478942.

12. Cardwell CR, Stene LC, Joner G et al. Caesarean section is associated with an increased risk of childhood-onset type 1 diabetes mellitus: a meta-analysis of observational studies. Diabetologia. 2008 May;51(5):726- 35. doi: 10.1007/s00125-008-0941-z. Epub 2008 Feb 22. PMID: 18292986.

13. Horta BL, Gigante DP, Lima RC, Barros FC, Victora CG. Birth by caesarean section and prevalence of risk factors for non-communicable diseases in young adults: a birth cohort study. PLoS One. 2013 Sep 9;8(9):e74301. doi: 10.1371/journal.pone.0074301. PMID: 24040224; PMCID: PMC3767800.

14. Li HT, Zhou YB, Liu JM. The impact of cesarean section on offspring overweight and obesity: a systematic review and meta-analysis. Int J Obes (Lond). 2013 Jul;37(7):893-9. doi: 10.1038/ijo.2012.195. Epub 2012 Dec 4. PMID: 23207407.

15. Kuhle S, Tong OS, Woolcott CG. Association between caesarean section and childhood obesity: a systematic review and meta-analysis. Obes Rev. 2015 Apr;16(4):295-303. doi: 10.1111/obr.12267. Epub 2015 Mar 5. PMID: 25752886.

16. Darmasseelane K, Hyde MJ, Santhakumaran S, Gale C, Modi N. Mode of delivery and offspring body mass index, overweight and obesity in adult life: a systematic review and meta-analysis. PLoS One. 2014 Feb 26;9(2):e87896. doi: 10.1371/journal.pone.0087896. Erratum in: PLoS One. 2014;9(5):e97827. PMID: 24586295; PMCID: PMC3935836.

17. Sutharsan R, Mannan M, Doi SA, Mamun AA. Caesarean delivery and the risk of offspring overweight and obesity over the life course: a systematic review and bias adjusted meta-analysis. Clin Obes. 2015 Dec;5(6):293301. doi: 10.1111/cob.12114. Epub 2015 Aug 19. PMID: 26286021.

18. Quecke B, Graf Y, Epure AM, Santschi V, Chiolero A, Carmeli C, Cullati S. Caesarean section and obesity in young adult offspring: Update of a systematic review with meta-analysis. Obes Rev. 2021 Sep 28:e13368. doi: 10.1111/obr.13368. Epub ahead of print. PMID: 34585502.

19. World Health Organization. Global database on body mass index: BMI classifications http://www.assessmentpsychology.com/icbmi.htm

20. Wells GA, Shea B, O'Connell D et al. The Newcastle-Ottawa Scale (NOS) for Assessing the Quality of Non randomized Studies in Meta-analyses. Ottawa: Ottawa Hospital Research Institute.

21. Higgins JP, Thompson SG, Deeks JJ, Altman DG. Measuring inconsistency in metaanalyses. BMJ. 2003 Sep 6;327(7414):557-60. doi: 10.1136/bmj.327.7414.557. PMID: 12958120; PMCID: PMC192859.

22. Begg CB, Mazumdar M. Operating characteristics of a rank correlation test for publication bias. Biometrics. 1994 Dec;50(4):1088-101. PMID: 7786990.

23. Egger M, Davey Smith G, Schneider M, Minder C. Bias in meta-analysis detected by a simple, graphical test. BMJ. 1997 Sep 13;315(7109):629-34. doi: 10.1136/bmj.315.7109.629. PMID: 9310563; PMCID: PMC2127453.

24. Stroup DF, Berlin JA, Morton SC et al. Meta-analysis of observational studies in epidemiology: a proposal for reporting. Meta-analysis Of Observational Studies in Epidemiology (MOOSE) group. JAMA. 2000 Apr 19;283(15):2008-12. doi: 10.1001/jama.283.15.2008. PMID: 10789670. 
25. Moher D, Liberati A, Tetzlaff J, Altman DG; PRISMA Group. Preferred reporting items for systematic reviews and meta-analyses: the PRISMA statement. PLoS Med. 2009 Jul 21;6(7):e1000097. doi: 10.1371/journal.pmed.1000097. Epub 2009 Jul 21. PMID: 19621072; PMCID: PMC2707599.

26. Mesquita DN, Barbieri MA, Goldani HA et al. Cesarean Section Is Associated with Increased Peripheral and Central Adiposity in Young Adulthood: Cohort Study. PLoS One. 2013 Jun 27;8(6):e66827. doi: 10.1371/journal.pone.0066827. PMID: 23826150; PMCID: PMC3694972.

27. Kuhle S, Woolcott CG. Caesarean section is associated with offspring obesity in childhood and young adulthood. Evid Based Med. 2017 Jun;22(3):111. doi: 10.1136/ebmed-2017-110672. Epub 2017 Mar 23. PMID: 28341620.

28. Araújo J, Severo M, Barros H, Mishra GD, Guimarães JT, Ramos E. Developmental trajectories of adiposity from birth until early adulthood and association with cardiometabolic risk factors. Int J Obes (Lond). 2015 Oct;39(10):1443-9. doi: 10.1038/ijo.2015.128. Epub 2015 Jul 9. PMID: 26155921.

29. Ahlqvist VH, Persson M, Magnusson C, Berglind D. Elective and nonelective cesarean section and obesity among young adult male offspring: A Swedish population-based cohort study. PLoS Med. 2019 Dec 6;16(12):e1002996. doi: 10.1371/journal.pmed.1002996. PMID: 31809506; PMCID: PMC6897402.

30. Goldani HA, Bettiol H, Barbieri MA et al. Cesarean delivery is associated with an increased risk of obesity in adulthood in a Brazilian birth cohort study. Am J Clin Nutr. 2011 Jun;93(6):1344-7. Doi: 10.3945/ajcn.110.010033. Epub 2011 Apr 20. PMID: 21508088.

31. Rooney BL, Mathiason MA, Schauberger CW. Predictors of obesity in childhood, adolescence, and adulthood in a birth cohort. Matern Child Health J. 2011 Nov;15(8):1166-75. doi: 10.1007/s10995-010-0689-1. PMID: 20927643.

32. Barros FC, Matijasevich A, Hallal PC et al. Cesarean section and risk of obesity in childhood, adolescence, and early adulthood: evidence from 3 Brazilian birth cohorts. Am J Clin Nutr. 2012 Feb;95(2):465-70. doi: 10.3945/ajcn.111.026401. Epub 2012 Jan 11. PMID: 22237058; PMCID: PMC3260073.

33. Mamun AA, Sutharsan R, O'Callaghan M et al. Cesarean delivery and the long-term risk of offspring obesity. Obstet Gynecol. 2013 Dec;122(6):1176-83. doi: 10.1097/AOG.0000000000000016. PMID: 24201680.

34. Yuan C, Gaskins AJ, Blaine AI et al. Association Between Cesarean Birth and Risk of Obesity in Offspring in Childhood, Adolescence, and Early Adulthood. JAMA Pediatr. 2016 Nov 7;170(11):e162385. doi: 10.1001/jamapediatrics.2016.2385. Epub 2016 Nov 7. PMID: 27599167; PMCID: PMC5854473.

35. Hansen S, Halldorsson TI, Olsen SF et al. Birth by cesarean section in relation to adult offspring overweight and biomarkers of cardiometabolic risk. Int J Obes (Lond). 2018 Jan;42(1):15-19. Doi: 10.1038/ijo.2017.175. Epub 2017 Jul 31. PMID: 28757643.

36. Chavarro JE, Martín-Calvo N, Yuan C et al. Association of Birth by Cesarean Delivery With Obesity and Type 2 Diabetes Among Adult Women. JAMA Netw Open. 2020 Apr 1;3(4):e202605. Doi: 10.1001/jamanetworkopen.2020.2605. PMID: 32282045; PMCID: PMC7154804.

37. Martín-Calvo N, Martínez-González MÁ, Segura G, Chavarro JE, Carlos S, Gea A. Caesarean delivery is associated with higher risk of overweight in the offspring: within-family analysis in the SUN cohort. J Epidemiol Community Health. 2020 Jun;74(7):586-591. doi: 10.1136/jech-2019-213724. Epub 2020 Apr 24. PMID: 32332117; PMCID: PMC7293569. 
38. Sogunle E, Masukume G, Nelson G. The association between caesarean section delivery and later life obesity in 21-24 year olds in an Urban South African birth cohort. PLoS One. 2019 Nov 14;14(11):e0221379. doi: 10.1371/journal.pone.0221379. PMID: 31725725; PMCID: PMC6855451.

39. Svensson E, Hyde M, Modi N, Ehrenstein V. Caesarean section and body mass index among Danish men. Obesity (Silver Spring). 2013 Mar;21(3):429-33. doi: 10.1002/oby.20310. PMID: 23408746.

40. Malik VS, Willett WC, Hu FB. Global obesity: trends, risk factors and policy implications. Nat Rev Endocrinol. 2013 Jan;9(1):13-27. doi: 10.1038/nrendo.2012.199. Epub 2012 Nov 20. PMID: 23165161.

41. Rutayisire E, Huang K, Liu Y, Tao F. The mode of delivery affects the diversity and colonization pattern of the gut microbiota during the first year of infants' life: a systematic review. BMC Gastroenterol. 2016 Jul 30;16(1):86. doi: 10.1186/s12876- 016-0498-0. PMID: 27475754; PMCID: PMC4967522.

42. Neu J, Rushing J. Cesarean versus vaginal delivery: long-term infant outcomes and the hygiene hypothesis. Clin Perinatol. 2011 Jun;38(2):321-31. doi: 10.1016/j.clp.2011.03.008. PMID: 21645799; PMCID: PMC3110651.

43. Kalliomäki M, Collado MC, Salminen S, Isolauri E. Early differences in fecal microbiota composition in children may predict overweight. Am J Clin Nutr. 2008 Mar;87(3):534-8. doi: 10.1093/ajcn/87.3.534. PMID: 18326589.

44. Schlinzig T, Johansson S, Gunnar A, Ekström TJ, Norman M. Epigenetic modulation at birth - altered DNAmethylation in white blood cells after Caesarean section. Acta Paediatr. 2009 Jul;98(7):1096-9. doi: 10.1111/j.16512227.2009.01371.x. PMID: 19638013.

45. Armstrong J, Reilly JJ; Child Health Information Team. Breastfeeding and lowering the risk of childhood obesity. Lancet. 2002 Jun 8;359(9322):2003-4. doi: 10.1016/S0140-6736(02)08837-2. PMID: 12076560.

46. Betran AP, Torloni MR, Zhang JJ, Gülmezoglu AM; WHO Working Group on Caesarean Section. WHO Statement on Caesarean Section Rates. BJOG. 2016 Apr;123(5):667-70. doi: 10.1111/1471-0528.13526. Epub 2015 Jul 22. PMID: 26681211; PMCID: PMC5034743.

47. Quin C, Estaki M, Vollman DM, Barnett JA, Gill SK, Gibson DL. Probiotic supplementation and associated infant gut microbiome and health: a cautionary retrospective clinical comparison. Sci Rep. 2018 May 29;8(1):8283. doi: 10.1038/s41598-018-26423-3. PMID: 29844409; PMCID: PMC5974413. 